\title{
Effect of the catalyst on the physical and aroma attributes of interesterified milk fat-vegetable oil blends
}

\section{Efeito do catalisador nos atributos físicos e aromáticos de blendas interesterificadas de gordura de leite e óleos vegetais}

\author{
Mayara Ribeiro Rocha', Renata Nazaré Vilas Bôas', Francisco Carlos Biaggio', Heizir Ferreira de Castro1* (i), \\ Domingos Sávio Giordani' ${ }^{1}$
}

1 Universidade de São Paulo (USP), Escola de Engenharia de Lorena, Departamento de Engenharia Química, Lorena/SP - Brasil

\section{*Corresponding Author}

Heizir Ferreira de Castro, Universidade de São Paulo (USP), Escola de Engenharia de Lorena, Departamento de Engenharia Química, Estrada Municipal do Campinho, s/n, CEP: 12602-810, Lorena/SP - Brasil, e-mail: heizir@dequi.eel.usp.br

Cite as: Effect of the catalyst on the physical and aroma attributes of interesterified milk fat-vegetable oil blends. Braz. J. Food Technol., v. 21, e2018036, 2018.

\section{Abstract}

Received: Feb. 13, 2018; Accepted: June 28, 2018

The present study aimed to verify the influence of the catalyst (sodium methoxide and the lipase from Rhizopus oryzae immobilized on a hybrid support - silica-polyvinyl alcohol) on the physical and aroma attributes of the products obtained from the interesterification of milk fat with vegetable oils (soybean and canola). The evaluation was carried out using an electronic nose (e-nose) and a texture analyzer. Interesterification reactions were carried out with binary blends (65\% of milk fat and $35 \%$ of vegetable oil) using $0.75 \%$ sodium methoxide $\left(60{ }^{\circ} \mathrm{C}\right.$ for $60 \mathrm{~min}$ ) and immobilized Rhizopus oryzae lipase at a fixed proportion of 500 units of activity per gram of blend $\left(45^{\circ} \mathrm{C}\right.$ for $\left.6 \mathrm{~h}\right)$. The results showed that the e-nose sensors discriminated satisfactorily the aromas of both raw materials and products and were able to distinguish them according to the catalyst used. In relation to the texture, both catalysts generated products with appropriate consistencies with satisfactory plasticity and spreadability at refrigerator temperatures.

Keywords: Milk fat; Vegetable oils; Interesterification; Catalyst; Aroma; Consistency.

\section{Resumo}

O presente estudo teve como objetivo verificar a influência do catalisador (metóxido de sódio e lipase de Rhizopus oryzae imobilizada em suporte híbrido - sílica-álcool polivinílico) nos atributos físicos e no aroma dos produtos obtidos a partir da interesterificação da gordura do leite com óleos vegetais (soja e canola). A avaliação foi feita usando nariz eletrônico e texturômetro. As reações de interesterificação foram realizadas com misturas binárias (65\% de gordura do leite e 35\% de óleo vegetal), usando metóxido de sódio $0,75 \%\left(60{ }^{\circ} \mathrm{C}\right.$ por $60 \mathrm{~min}$ ) e lipase de Rhizopus oryzae imobilizada na proporção de 500 unidades de atividade por grama de mistura $\left(45^{\circ} \mathrm{C}\right.$ durante $6 \mathrm{~h}$ ). Os resultados mostraram que os sensores do nariz eletrônico discriminaram de forma satisfatória os aromas das matérias-primas e dos produtos e foram capazes de distingui-los de acordo com o catalisador utilizado. Em relação à textura, ambos os catalisadores geraram produtos com consistências adequadas, revelando plasticidade satisfatória e espalhabilidade sob temperatura de geladeira.

Palavras-chave: Gordura do leite; Óleos vegetais; Interesterificação; Catalisador; Aroma; Consistência. 


\section{Introduction}

Milk fat is the third largest source of lipids for human nutrition, showing flavour and aroma superior to any other edible fat (REDDY, 2010). It consists of a blend of more than 100,000 different types of triglycerides containing about 400 different fatty acids with large amounts of both long-chain (16 to 18 carbon atoms) and short-chain (4 to 10 carbon atoms) acids (KONTKANEN et al., 2011). Such a varied composition, probably the most complex one amongst fatty foods, is responsible for the flavour and unique physical properties, giving the milk fat superior quality in the various food sensory impressions. Despite possessing desirable characteristics and being widely appreciated by consumers, milk fat shows some drawbacks concerning health, such as those related to saturated fats (KONTKANEN et al., 2011). Of the constituent fatty acids, there is also a large percentage of hypercholesterolemic (medium-chain saturated) fatty acids located predominantly in position sn-2 of the triacylglycerol (LUBARY et al., 2011). Excessive consumption of this type of fat has been associated with cardiovascular diseases (IMRAN; NADEEM, 2015). The physical and sensory characteristics of milk fat also play a significant role in its market and public acceptance. Milk fat, for instance, has low spreadability at domestic refrigeration temperatures (RODRIGUES-RACT et al., 2010), which has frequently been reported by consumers as a drawback when compared to margarine and vegetable oil spreads. In this sense, replacing butter by margarines or vegetable creams has led the industry to seek processes to modify milk fat, aiming to increase the alternatives for use of this raw material (KAUFMANN et al., 2012; KONTKANEN et al., 2011).

The transformation of milk fat via chemical or enzymatic processes is often considered as a promising modification in order to attend market needs. Interesterification is one of these processes, and consists of the exchange of acyl groups from one fatty ester to another. The interesterification of milk fat has been reported to yield significant changes in the physical properties, including the spreadability, due to the redistribution of the fatty acids bonded to the triacylglycerol chains (RØNNE et al., 2005). Using the chemical transformation route, metallic sodium or a sodium salt of chloromethyl methyl ether are often used as catalysts, leading to the random redistribution of fatty acids on the triacylglycerol chains. Moreover, the operational conditions adopted (high temperature and pressure) provide additional steps of bleaching and deodorization of the final product. These steps may have harmful nutritional effects, besides extinguishing the butter flavour, highly appreciated by consumers (KONTKANEN et al., 2011; PAULA et al., 2016). On the other hand, the enzymatic pathway employs lipases (glycerol ester hydrolase EC 3.1.1.3) as biocatalysts, which provide little to no undesirable side reactions (ANDUALEMA; GESSESSE, 2012). Lipase-catalysed interesterification yields a pathway in which the fatty acids can be redistributed to characteristic positions when specific 1,3-lipases are used (KONTKANEN et al., 2011; O'BRIEN, 2009). 1,3-lipases act under mild reactive conditions of $\mathrm{pH}$, temperature and pressure, leading to reduced energy costs. Furthermore enzymes possess high specificity and represent a versatile tool for preparing a wide variety of TAGs (triacylglycerols) by minimizing by-product formation (O'BRIEN, 2009; SILVA et al., 2009).

Different vegetable oils have been described as suitable for interesterification with milk fat, such as canola and soybean oils. The selection procedure adopted in the literature is dependent on the oil characteristics, which can then lead to the desirable physical, nutritional and sensory properties being conferred on the final interesterified product. The modified product thus becomes a function of the fatty acid composition (KONTKANEN et al., 2011). Soybean and canola are commonly reported due to their fatty acid profiles, which are composed of significant quantities of essential fatty acids, as well as linoleic and linolenic acids and unsaturated fats. This desired composition has been associated with a decrease in cholesterol levels and the risk of heart coronary diseases, as well as a decrease in the probability of tumour development (KONTKANEN et al., 2011).

In addition, changes in the triacylglycerols may lead to changes in their physical properties and to differences in the aroma and flavour intensities of a given product. One of the traditional and widely accepted methods of evaluating the acceptability of a modified food product is by using human panels. Palate experiences and voluntary grading of one's experience and impressions about a product represent the procedure used for panel-based sensory analyses, which are further quantified via a questionnaire. Despite the wide acceptance of such an approach, a common reported drawback is the prolonged timeline for a given study due to, amongst other reasons, the mandatory adoption of often-bureaucratic committee rules of the research institution. As an alternative to the human-based approach, the authors present the application of an electronic nose (e-nose) in this article. An e-nose is a piece of equipment that mimics the human olfactory system and is able to efficiently differentiate odours with small differences one from the other (GIORDANI et al., 2008). Unlike other analytical instruments (e.g. gas chromatography, chemical sensors, biosensors, mass spectrometers), this device allows for the identification of blends of organic specimens as a whole, without having to identify the individual chemical species. A typical e-nose consists of different sensors, which choose to respond to a wide range of chemical classes and further discriminate various blends of possible analytes (RÖCK et al., 2008). There are numerous applications of e-noses ranging from environmental monitoring to medical applications. Since 
1993, more than 12,000 articles have been published in the area of electronic olfaction. The main application areas related to the food industry are found in the fish, meat, milk, wine, coffee and tea industries, and constitute approximately 5000 publications since 1993. This demonstrates that food applications are central to electronic olfaction and nearly half of the publications are in this area. Within each application in the food industry, research contributions have focused on the detection of a variety of aspects such as freshness, adulteration, off-flavours and bacterial detection (LOUTFI et al., 2015). Thus the experiments presented in this article analysed the physical and aroma attributes of interesterified products formed by both the chemical and enzymatic routes from binary blends of milk fat and vegetable oils (soybean and canola), aiming to identify the influence of the type of catalyst on the aroma (electronic nose) and texture of the interesterified samples.

\section{Material and methods}

\subsection{Materials}

The experiments were performed using a microbial lipase from Rhizopus oryzae (lipase L036P, Biocatalysts, Cardiff, England), classified as 1,3-specific lipase and immobilized on a hybrid support of polysiloxane-polyvinyl alcohol ( $\mathrm{SiO}_{2}$-PVA) prepared using the sol-gel technique according to the methodology described by Paula et al. (2016), employing tetraethyl orthosilicate (TEOS) (Sigma-Aldrich Chemical, St. Louis, USA) as a the precursor. The $R$. oryzae lipase was pre-selected as a result of previous research developed to catalyse interesterification reactions (PAULA et al., 2016). Powdered sodium methoxide was used as the chemical catalyst (Merck, Germany).

Milk fat was obtained from a commercial butter (Qualita ${ }^{\circledR}$, unsalted), with controlled heating at $50^{\circ} \mathrm{C}$ in a microwave oven. The melted product was then submitted to centrifugation and separation of the aqueous phase. Soybean oil (Qualita ${ }^{\circledR}$ ) and canola oil (Qualita ${ }^{\circledR}$ ) were obtained from a local market in their refined versions, and were used without additional treatment. Samples of commercial margarines (Doriana ${ }^{\circledR}$ and Qualy ${ }^{\circledR}$ ) acquired from the local market were used as benchmarks for comparison of the properties of the products obtained by chemical and enzymatic interesterification.

Solvents (heptane, hexane, acetone and ethanol) were obtained from Cromoline (São Paulo, Brazil). The other materials and reagents were acquired commercially, all of an analytical grade.

\subsection{Lipase immobilization}

The hybrid support ( $\mathrm{SiO}_{2}$-PVA) was synthesized by the sol-gel technique using TEOS as a precursor according to the methodology described by Paula et al. (2016). It provided a matrix with the following texture characteristics: specific surface area $\left(461 \mathrm{~m}^{2} \mathrm{~g}^{-1}\right)$, specific pore volume $\left(0.275 \mathrm{~cm}^{3} \mathrm{~g}^{-1}\right)$, and average pore diameter of $22.9 \AA$. The support was subsequently activated by epichlorohydrin and the epoxy matrix (epoxy-SiO 2 -PVA) was used to immobilize the $R$. oryzae lipase by employing $250 \mathrm{mg}$ of lipase in its free form per gram of the activated support (dry matter) and $100 \mu \mathrm{L}$ of an aqueous solution containing $5 \mathrm{mg} \mathrm{mL}^{-1}$ of PEG-1500. The resulting immobilized derivative showed enzymatic activity of $3465 \mathrm{U} \mathrm{g}^{-1}$ as determined using the olive oil hydrolysis method (PAULA et al., 2016), and low water contents $(<8 \%)$.

\subsection{Procedure for the interesterification reactions}

The enzymatic interesterification reactions were carried out in jacketed cylindrical reactors operating in the batch mode, loaded with $70 \mathrm{~g}$ of the medium containing $65 \%$ of milk fat and $35 \%$ soybean or canola oils. The reaction mixtures were incubated with the immobilized lipase in the fixed proportion of 500 activity units per gram of the medium (500 $\mathrm{U} \mathrm{g}^{-1}$ ). The reactions were allowed to proceed for $6 \mathrm{~h}$ under magnetic stirring, in a dark, inert atmosphere $\left(\mathrm{N}_{2}\right)$ at $45^{\circ} \mathrm{C}$.

The chemical interesterification reactions were prepared using $320 \mathrm{~g}$ of milk fat and vegetable oil blends (65/35\%, wt.) The blends were dried on a rotary evaporator for $30 \mathrm{~min}$ at $90{ }^{\circ} \mathrm{C}$ and $0.75 \%$ of the sodium methoxide catalyst was subsequently added. The chemical interesterification reactions were allowed to proceed under reduced pressure at $60{ }^{\circ} \mathrm{C}$ for $60 \mathrm{~min}$, with stirring. At the end of the reaction, $3 \mathrm{~mL}$ of distilled water were added to inactivate the catalyst. Sodium sulphate was then added to eliminate excess water. The resulting blend was hot-filtered for removal of the soaps and dark compounds formed.

\subsection{Analytical methods}

The moisture content of the milk fat and vegetable oils was determined by Karl Fisher titration according to the official method Ca 2e-84 of the American Oil Chemist's Society (FIRESTONE, 2004). The acidity indexes, and the saponification, iodine and peroxide values of the raw materials were determined according to the standard methods recommended by the American Oil Chemist's Society (FIRESTONE, 2004), showing values within the limits established by Brazilian legislation (BRASIL, 2006) (Table 1).

\subsection{Consistency}

The consistency of the samples was determined using a texturometer (QTS 25 Texture Analyzer), controlled by the Texture Pro software. The samples were heated in a microwave oven $\left(45^{\circ} \mathrm{C}\right.$ to $\left.50^{\circ} \mathrm{C}\right)$ for full fusion of the crystals and then packed into cubic silicone moulds (25-mm edge). The conditioning proceeded for $48 \mathrm{~h}$ at a 
Effect of the catalyst on the physical and aroma attributes of interesterified milk fat-vegetable oil blends

Rocha, M. R. et al.

Table 1. Acidity indexes, values of saponification, iodine, and peroxide of the raw materials utilized and compared to values established by Brazilian legislation.

\begin{tabular}{|c|c|c|c|c|c|}
\hline Raw material & $\begin{array}{l}\text { Observed / } \\
\text { Legislation* }\end{array}$ & $\begin{array}{l}\text { Acidity index } \\
\left(\mathrm{mg} \mathrm{KOH} \mathbf{g}^{-1}\right)\end{array}$ & 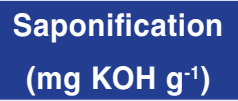 & $\begin{array}{c}\text { lodine } \\
(\mathrm{g} \mathrm{I} / 100 \mathrm{~g})\end{array}$ & $\begin{array}{l}\text { Peroxide } \\
\left(\text { meq } g^{-1}\right)\end{array}$ \\
\hline \multirow{2}{*}{ Soybean oil } & Observed & 0.16 & 189 & 116 & 0.94 \\
\hline & Legislation & $\leq 0.20$ & 189-195 & $124-139$ & $\leq 2.5$ \\
\hline \multirow{2}{*}{ Canola oil } & Observed & 0.13 & 191 & 104 & 1.2 \\
\hline & Legislation & $\leq 0.20$ & $182-193$ & $105-126$ & $\leq 2.5$ \\
\hline \multirow{2}{*}{ Milk fat } & Observed & $1.6^{\star *}$ & 231 & 32 & 0.67 \\
\hline & Legislation & $\max 3^{\star \star}$ & 218-325 & $28-38$ & $\max 1$ \\
\hline
\end{tabular}

${ }^{*}$ Brasil (2006); **mmol/100 g.

controlled temperature $\left(10^{\circ} \mathrm{C}\right)$, suitable for fat recrystallization. A TA15 probe corresponding to an acrylic cone with the tip in its non-truncated form at a $45^{\circ}$ angle was used. The tests were carried out under the following conditions: distance from the return to the beginning: $10 \mathrm{~mm}$; speed: $120 \mathrm{~mm} / \mathrm{min}$; time: $5 \mathrm{~s}$; determination of the compression force (gf) in duplicate. The samples were analysed for the "yield value" calculated according to Equation 1 and the results correlated with the criterion established by Haighton (1959):

$$
C=K \frac{W}{p^{1.6}}
$$

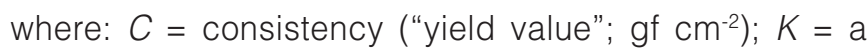
factor whose value depends on the cone angle (for $45^{\circ}$, 4700); $W=$ maximal compression force ( $g$ f) after the time of $5 \mathrm{~s} ; p=$ penetration depth $(0.1 \mathrm{~mm})$.

In the specific case of this trial, a consistency range

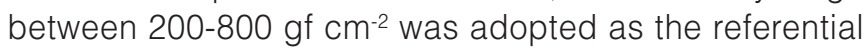
parameter (satisfactory plasticity and spreadability).

\subsection{E-nose}

Data collection was carried out by a model Cyranose 320TM E-nose of the Smiths Detection brand, manufactured by CyranoSciences Inc, USA), based on suction of the headspace sample and recording the results produced by the sensors. The sensors were composites of conductive polymers and carbon nanoparticles that, when exposed to the specimen vapours, could absorb part of these, affecting their dimensional alterations and, consequently, their electrical resistance, which was then measured and recorded for further statistical analysis (WILSON; BAIETTO, 2009).

For the characterization of the components studied, a $180 \mathrm{~cm}^{3} \mathrm{~min}^{-1}$ flow was used for air suction and one of $50 \mathrm{~cm}^{3} \mathrm{~min}^{-1}$ for the headspace, with times of $10 \mathrm{~s}$ and $60 \mathrm{~s}$, respectively. Five $\mathrm{mL}$ aliquots of each oil and milk fat sample were packed into ten containers for testing. Binary blends of milk fat (65\%) and vegetable oil (35\%) were also analysed under the same conditions. The PCnose software was used to establish the analytical conditions and the data analysed using the Principal Component Analysis (PCA), which is a multivariate technique used to emphasize the variation and capture robust patterns in the data set. This technique uses orthogonal transformation predictive and exploratory data analysis. The orthogonal transformation then converts the set of observations of possibly correlated variables into a set of values of non-correlated linear variables called principal components. Thus the method uses sets of variables with different dimensions and by way of linear transformations, decreases the amount of variables, preserving the variance between them, so that quantities are converted into dimensionless vectors.

In the present work, the PCA data resulted in the visualization of three dimensions of the information produced by the 32-sensor array used in the equipment (ABDI; WILLIAMS, 2010). As PCA information preserves the original sensor information in a 3-dimensional graph, nearby spatial regions denote similar odours.

\section{Results and discussion}

\subsection{Analysis of raw materials and binary blends}

Initially, the raw materials (milk fat, soybean oil, and canola oil) and the binary blends were analysed for their consistencies, and Table 2 shows the values obtained together with the assessment of the degree of spreadability according to the criteria established by Haighton (1959). It was observed that the milk fat exhibited a mean consistency value of $2785 \mathrm{gf} \mathrm{cm}^{-2}$, equivalent to an assessment of "very hard". The consistency of the commercial butter was $2002 \mathrm{gf} \mathrm{cm}^{-2}$, also characterized as "very hard"

It was also noted that the addition of vegetable oil to milk fat in the proportion of 35\% reduced the consistency of the blend by 58\% (milk fat and soybean oil) and 55\% (milk fat and canola oil), improving their degree of spreadability, yet maintaining the classification as "very hard".

Regarding the olfactory profiles shown in Figure 1, it was found that the vegetable oils presenting similar aromas, which are concentrated on the left side of the figure 
Effect of the catalyst on the physical and aroma attributes of interesterified milk fat-vegetable oil blends

Rocha, M. R. et al.

(soybean oil, in blue, and canola oil, in orange). In contrast, the isolated milk fat aroma (red) was concentrated on the right side of the figure, showing a distinct aroma as compared to that of the other raw materials. In the blends, the aroma of the milk fat prevailed, since it was present in greater amounts, and hence the concentration of the data points was closer to those of this raw material.

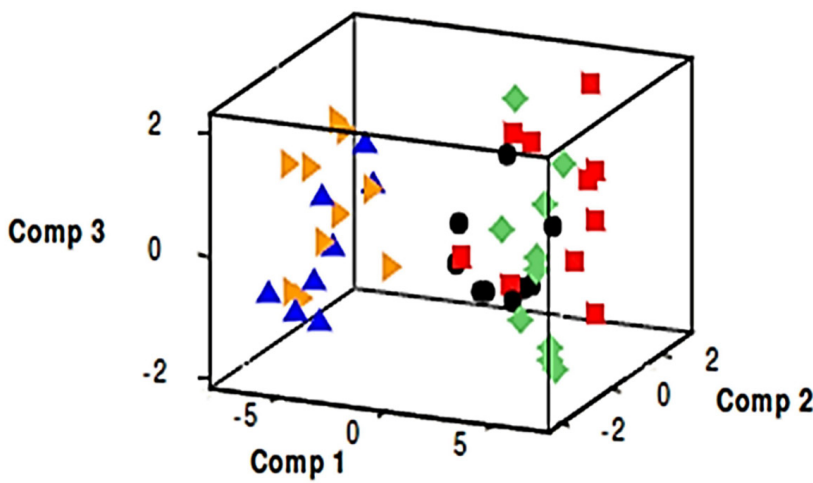

Figure 1. Profiles of the aromas of the components of the binary blend of milk fat with soybean oil (green diamonds) and milk fat with canola oil (red squares), and the main raw materials: milk fat (black circles), canola oil (blue triangles) and soybean oil (orange triangles).

\subsection{Assessment of the consistency of the interesterified products}

The interesterified products obtained by the chemical and enzymatic routes were evaluated in terms of consistency (Table 3) and then compared with those of commercial margarines. Regardless of the oil utilized, both routes provided interesterified products with appropriate consistency values that allowed for their classification according to the Haighton criteria, as having "satisfactory plasticity and spreadability". The reduction in the consistency of the interesterified products in relation to that of the binary blends, was higher by the chemical route (average reduction of $52.5 \%$ ) than by the enzymatic route (average reduction of $45 \%$ ), probably due to the different reactional conditions employed (e.g. difference in temperature). In comparison with the commercially available margarines, the interesterified products obtained by the chemical route showed consistencies closer to that of Doriana ${ }^{\circledR}$ margarine (DMAG), whereas the products obtained by the enzymatic route showed consistencies closer to that of Qualy ${ }^{\circledR}$ margarine (QMAG).

\subsection{Aroma assessment of the interesterified products}

The olfactory profiles of the principal components before and after the chemical and enzymatic interesterification reactions of the binary blends can be

Table 2. Consistency values of the raw materials and blends.

\begin{tabular}{lccc}
\multicolumn{1}{c}{ Components } & $\begin{array}{c}\text { Consistency } \\
\text { Gf } \mathbf{~ m}^{-2}\end{array}$ & $\begin{array}{c}\text { Reduction* } \\
\text { (\%) }\end{array}$ & Haighton classification \\
Milk fat & $2785 \pm 83$ & - & Too hard \\
Blend of milk fat and soybean oil & $1159 \pm 169$ & 58 & Very hard, spreadability limit \\
Blend of milk fat and canola oil & $1260 \pm 176$ & 55 & Very hard, spreadability limit \\
Commercial butter & $2002 \pm 70$ & - & Too hard \\
\hline
\end{tabular}

${ }^{*}$ Calculated in relation to the consistency of the milk fat $(2785 \pm 83)$.

Table 3. Consistency values of interesterified products compared to those of margarine samples acquired commercially.

\begin{tabular}{|c|c|c|c|c|c|}
\hline \multirow{2}{*}{ Product } & \multicolumn{2}{|c|}{ Blend of milk fat and soybean oil } & \multicolumn{2}{|c|}{$\begin{array}{c}\text { Blend of milk fat and } \\
\text { canola oil }\end{array}$} & \multirow{2}{*}{ Classification } \\
\hline & $\begin{array}{l}\text { Consistency } \\
\text { (gf } \mathrm{cm}^{-2} \text { ) }\end{array}$ & $\begin{array}{c}\text { Reduction of } \\
\text { consistency* }(\%)\end{array}$ & $\begin{array}{l}\text { Consistency } \\
\text { (gf } \mathrm{cm}^{-2} \text { ) }\end{array}$ & $\begin{array}{c}\text { Reduction of } \\
\text { consistency** (\%) }\end{array}$ & \\
\hline $\begin{array}{l}\text { Interesterified by } \\
\text { chemical route }\end{array}$ & $545 \pm 3$ & 53 & $602 \pm 5$ & 52 & \multirow{4}{*}{$\begin{array}{c}\text { Satisfactory } \\
\text { plasticity and } \\
\text { spreadability }\end{array}$} \\
\hline $\begin{array}{l}\text { Interesterified by } \\
\text { enzymatic route }\end{array}$ & $658 \pm 11$ & 43 & $658 \pm 11$ & 47 & \\
\hline DMAG & $573 \pm 12$ & - & $573 \pm 12$ & - & \\
\hline QMAG & $648 \pm 15$ & - & $648 \pm 15$ & - & \\
\hline
\end{tabular}

${ }^{*}$ Calculated in relation to the consistency of the milk fat and soybean oil blend $\left(1159 \pm 169 \mathrm{gf} \mathrm{cm}^{-2}\right) ;{ }^{*}$ Calculated in relation to the consistency of

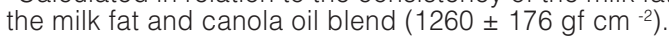


seen in the Supplementary Material (milk fat with soybean oil, Figures. S1-S2 and milk fat with canola oil, Figures. S3-S4). The observation of these profiles suggests that the aroma of the interesterified products changed when compared with the profiles of the principal components.

Figures 2 and 3 compare the olfactory profiles of the interesterified products obtained by the chemical and enzymatic routes of the binary blends: milk fat with soybean oil and milk fat with canola oil, respectively. In both figures, it can be seen that each interesterified product exhibited a singular aroma that differed from those of the raw materials and blends as such.

In the case of the interesterification of the binary blend of milk fat with soybean oil (Figure 2), the product interesterified by the chemical route is shown in blue in the

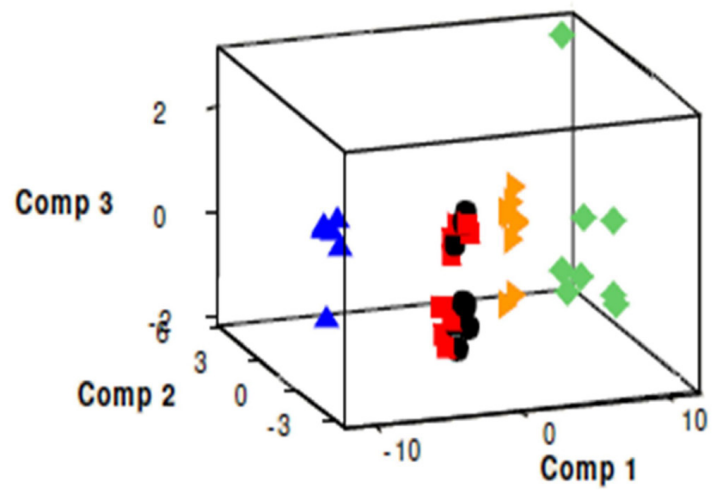

Figure 2. Profiles of the aromas of the interesterified products produced by the chemical route (blue triangles) and the enzymatic route (green diamonds), of the binary blend of milk fat with soybean oil (red squares) and of the raw materials: milk fat (black circles) and soybean oil (orange triangles).

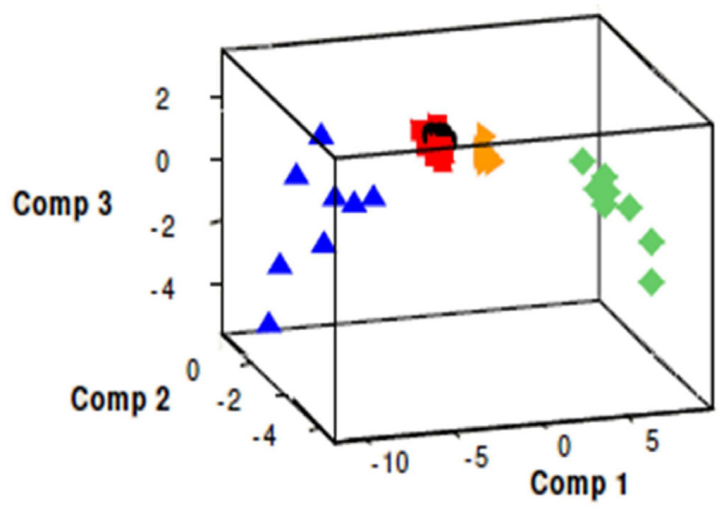

Figure 3. Profiles of the aromas of the interesterified products produced by the chemical route (blue triangles), enzymatic route (green diamonds), of the binary blend of milk fat with soybean oil (red squares) and of the raw materials: milk fat (black circles) and soybean oil (orange triangles). left corner of the figure, while the product interesterified by the enzymatic route appears in the right corner of the figure, in green. Milk fat, soybean oil and the blend of milk fat with soybean oil appear in black, red, and orange, respectively, in the centre of the figure. The same behaviour was observed for the interesterified products of the binary blend of milk fat and canola oil (Figure 3), i.e. the interesterified product obtained from the chemical route appears in blue in the left corner of the figure, while the product interesterified by the enzymatic route appears in green in the right corner of the figure. Thus, each interesterification route shows a singular aroma that differs from those of the raw materials and of the blends as such. Nevertheless, in both cases, regardless of the vegetable oil used, the olfactory profiles of the interesterified products were recorded on the opposite sides of the figure: the chemical route on the left hand side and the enzymatic route on the right hand side.

By matching the products generated in the interesterification reactions of the two binary blends, it can be clearly seen that both routes significantly changed the consistency values and the aromas of the binary blends. Regarding the consistency values of the interesterified products, significant differences between the performances of the catalysts were not verified, i.e. both promoted a reduction in consistency of the final products, allowing them to fit into the desired qualifying range (200 to $800 \mathrm{gf} \mathrm{cm}^{-2}$ ) according to the Haighton criteria. However, the aromas of the products were strongly influenced by the type of catalyst used. This fact may be better explained via the mechanisms of action using the chemical and enzymatic catalysts (Figure 4). Whereas using the chemical route the fatty acids were randomly redistributed (Figure 4a), using the enzymatic route with a 1,3-specific lipase such as that used in the present study (Figure 4b), the fatty acids were redistributed in characteristic positions (1,3 of the triacylglycerol).

The results obtained, when compared with the data described in the literature, indicate similar behavior, particularly with respect to the results published by Rousseau and Marangoni (1998). In this study, the comparison of the physical and olfactory properties of the interesterified products obtained by the chemical and enzymatic routes from canola oil and milk fat blends revealed more intense changes in the attributes when using the enzymatic route than in those of the products obtained by chemical interesterification. Using a human panel as the quality indicator, the results pointed to an aroma loss in the products obtained by chemical interesterification due to the catalyst used, further amplified by additional steps such as washing and purification of the final product. On the other hand, the interesterified products obtained by the enzymatic route showed aromas resulting from an increase in short-chain fatty acids as well as from the fact 
a)<smiles>OC(CS)(CS)[O+]1CCPC1</smiles>

b)
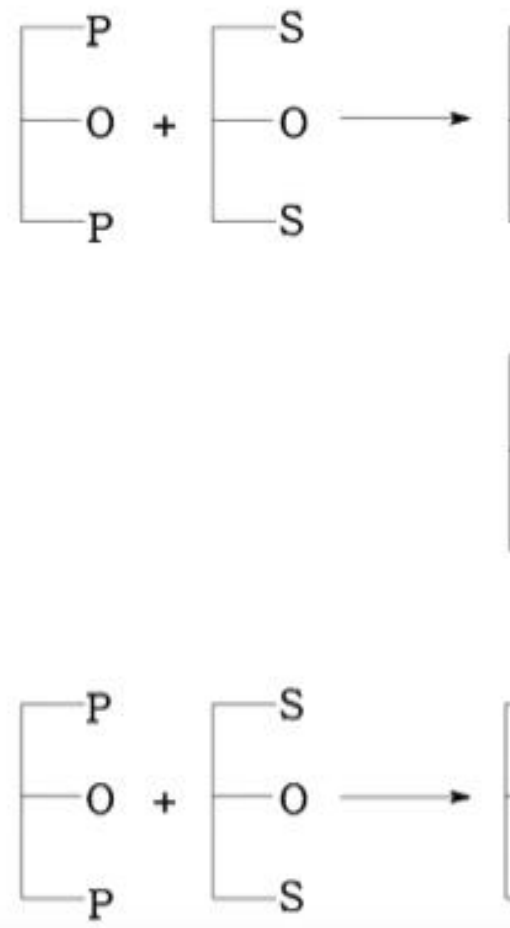<smiles>OCC([PH+])(CP)[PH+]1CCPC1</smiles><smiles>PCC1CPC1</smiles><smiles>c1nc(PC2CCP2)cs1</smiles><smiles>PCC(S)CP</smiles><smiles>OC(CP)C[PH2+]</smiles><smiles>OCC1COC1</smiles><smiles>OCC1CPC1</smiles><smiles>OCC1COC1</smiles><smiles>OCC1CCSC1</smiles><smiles>OCC(CO)[SH+][C@@H](S)CP</smiles><smiles>SCC1CSC1</smiles><smiles>CS[SnH2]c1ccccc1</smiles><smiles>SCC1CSC1</smiles><smiles>SCC1CCSC1</smiles><smiles>OC[C@H]1CSC[C@H]1S</smiles><smiles>PCC1CPC1</smiles><smiles>SCC1CCSC1</smiles><smiles>[PH3+]OCC(CS)=[SH+][PH3-]</smiles>

Figure 4. Interesterified products obtained using (a) chemical interesterification and (b) enzymatic interesterification catalyzed by a 1,3-specific lipase. The letters $\mathrm{P}, \mathrm{O}$ and $\mathrm{S}$ represent the palmitic, oleic and stearic acids (or residues of these acids linked to the triacylglycerol molecule), respectively.

that no subsequent purification treatments were needed. Thus the results described in the present work compared favourably with those described in the literature, where the use of the electronic nose was capable of very efficiently differentiating odours with small differences between them, being able to identify the influence of the type of catalyst in the aroma (e-nose) of the interesterified samples. The skill of the e-nose allows for a great expansion in the application of this tool in food quality research.

\subsection{Comparison of the aromas from the} interesterified products obtained by chemical and enzymatic reactions with those of commercial margarines and a commercial butter

Figure 5 presents a comparison of the olfactory profiles of the aromas of a commercial butter (Taubate ${ }^{\circledR}$ butter), two commercial margarines (DMAG and QMAG), and the interesterified products obtained by the chemical and enzymatic routes using two binary blends. The chemical route generated different aromas for each type of binary

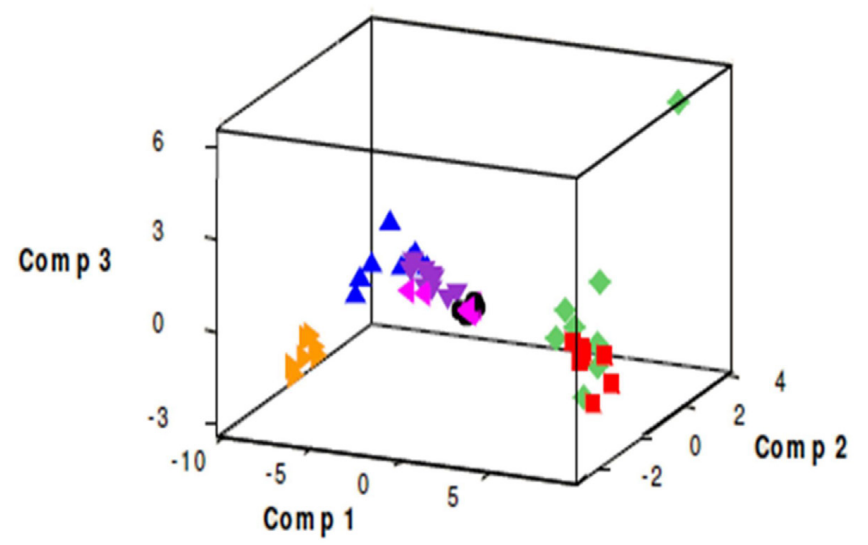

Figure 5. Comparison of the aromas of Taubate ${ }^{\circledR}$ butter (pink triangles), DMAG (black circles), QMAG (lilac triangles) and the interesterified products: from the enzymatic interesterification of milk fat with canola oil (red squares), enzymatic interesterification of milk fat with soybean oil (green diamonds), chemical interesterification of milk fat with canola oil (blue triangles) and the chemical interesterification of milk fat with soybean oil (orange triangles). 
Effect of the catalyst on the physical and aroma attributes of interesterified milk fat-vegetable oil blends

Rocha, M. R. et al.

blend (milk fat with soybean oil and milk fat with canola oil), explained by the non-specificity of the reaction, which redistributes the triacylglycerols at random. On the other hand, the enzymatic route generated interesterified products with similar aromas regardless of the oil utilized and the commercial products Taubate ${ }^{\circledR}$ butter, QMAG and DMAG provided results having similar aromas. It can also be seen that the aromas of the interesterified products produced by the chemical route were the closest to the dots corresponding to the aromas of the commercial margarines, once again confirming the sensitivity of the electronic nose and taking into account that commercial margarines are obtained by hydrogenation of vegetable oils by chemical catalysis.

Wang et al. (2010) studied the application of e-nose to identify different milk aromas and compared the results with those obtained by a sensory panel of trained evaluators. The results indicated that e-nose sensors could clearly and rapidly distinguish the natural milk aromas from the synthetic ones in milks, as well as that of the milk containing the induced enzyme. However, the trained human panel was unable to discriminate the natural milk aromas. The present work corroborated this conclusion, since it was possible to distinguish the type of interesterification process used via e-nose. However, since a sensory human panel has not yet been tested for this assessment, it is not possible to assert whether this type of panel will be able to make such a distinction.

\section{Conclusion}

The interesterification of milk fat is a promising alternative to overcome common drawbacks related to its use, such as limited spreadability at refrigeration temperatures. In this work, the properties of the interesterified products obtained by chemical and enzymatic routes from binary blends of milk fat and vegetable oils (soybean and canola) were assessed, aiming to identify the influence of the type of catalyst, whether chemical or enzymatic, on the aroma and texture of the interesterified products. Independent of the nature of the catalyst, the interesterified products showed similar physical attributes, although with different olfactory profiles. This fact can be attributed to the specificity of the enzymatic catalyst, which, by definition, reacts specifically with the 1,3 carbon bond of the triglycerides, while using the chemical catalyst the breakdown of the triglycerides is at random, resulting in fingerprints at opposite positions on the chart, suggesting that distinct aromas were formed through chemical and biochemical interesterification reactions. Thus it should be said that the catalyst has an important influence on the aromas of the products obtained by interesterification reactions. In addition, the application of e-nose has been shown to be a feasible tool to replace human panellists in food sensory studies. Further research could be done on many different food products, reducing the costs involved in quality assessment and simultaneously increasing the characterization profile.

\section{Acknowledgements}

The authors are grateful to CAPES (Coordenação de Aperfeiçoamento de Pessoal de Ensino Superior) and to CNPq (Conselho Nacional de Desenvolvimento Científico e Tecnológico) for their financial support.

\section{References}

ABDI, H.; WILLIAMS, L. J. Principal component analysis. Wiley Interdisciplinary Reviews: Computational Statistics, v. 2, n. 4, p. 433-459, 2010. http://dx.doi.org/10.1002/wics.101.

ANDUALEMA, B.; GESSESSE, A. Microbial lipases and their industrial applications: review. Biotechnology, v. 11, n. 3, p. 100-118, 2012. http://dx.doi.org/10.3923/biotech.2012.100.118.

BRASIL. Instrução normativa n 49, 22 de dezembro de 2006. Diário Oficial [da] República Federativa do Brasil, Brasília, DF, 26 dez. 2006.

FIRESTONE, D. (Ed.). Official methods and recommended practices of the AOCS. 5th ed. Champaigon: AOCS Press, 2004.

GIORDANI, D. S.; SIQUEIRA, A. F.; SILVA, M.; OLIVEIRA, P. C.; CASTRO, H. F. Identification of the biodiesel source using an electronic nose. Energy \& Fuels, v. 22, n. 4, p. 2743-2747, 2008. http://dx.doi.org/10.1021/ef700760b.

HAIGHTON, A. J. The measurement of the hardness of margarine and fats with cone penetrometers. Journal of the American Oil Chemists' Society, v. 36, n. 8, p. 345-348, 1959. http://dx.doi. org/10.1007/BF02640051.

IMRAN, M.; NADEEM, M. Triacylglycerol composition, physicochemical characteristics and oxidative stability of interesterified canola oil and fully hydrogenated cottonseed oil blends. Lipids in Health and Disease, v. 14, n. 138, p. 1-11, 2015. PMid:25575766.

KAUFMANN, N.; ANDERSEN, U.; WIKING, L. The effect of cooling rate and rapeseed oil addition on the melting behaviour, texture and microstructure of anhydrous milk fat. International Dairy Journal, v. 25, n. 2, p. 73-79, 2012. http://dx.doi.org/10.1016/j. idairyj.2012.02.004.

KONTKANEN, H.; ROKKA, S.; KEMPPINEN, A.; MIETTINEN, H.; HELLSTRÖM, J.; KRUUS, K.; MARNILA, P.; ALATOSSAVA, T.; KORHONEN, H. Enzymatic and physical modification of milk fat: a review. International Dairy Journal, v. 21, n. 1, p. 3-13, 2011. http://dx.doi.org/10.1016/j.idairyj.2010.05.003.

LOUTFI, A.; CORADESCHI, S.; MANI, G. K.; SHANKAR, P.; RAYAPPAN, J. B. B. Electronic noses for food quality: a review. Journal of Food Engineering, v. 144, p. 103-111, 2015. http:// dx.doi.org/10.1016/j.jfoodeng.2014.07.019. 
Effect of the catalyst on the physical and aroma attributes of interesterified milk fat-vegetable oil blends

Rocha, M. R. et al.

LUBARY, M.; HOFLAND, G. W.; TER HORST, J. H. The potential of milk fat for the synthesis of valuable derivatives. European Food Research and Technology, v. 232, n. 1, p. 1-8, 2011. http://dx.doi.org/10.1007/s00217-010-1387-3.

O'BRIEN, R. D. Fats and oils: formulating and processing for applications. 3rd ed. Florida: CRC Press, 2009.

PAULA, A. V.; NUNES, G. F. M.; CASTRO, H. F.; SANTOS, J. C. Assessing the reaction conditions to mediate the milk fat-soybean oil enzymatic interesterification. Brazilian Journal of Food Technology, v. 19, p. e2015116, 2016. http://dx.doi. org/10.1590/1981-6723.11615.

REDDY, S. Y. Improving plasticity of milk fat for use in baking by fractionation. Journal of the American Oil Chemists' Society, v. 87, n. 5, p. 493-497, 2010. http://dx.doi.org/10.1007/s11746009-1520-2.

RÖCK, F.; BARSAN, N.; WEIMAR, U. Electronic nose: current status and future trends. Chemical Reviews, v. 108, n. 2, p. 705-725, 2008. http://dx.doi.org/10.1021/cr068121q. PMid:18205411.

RODRIGUES-RACT, J. N.; COTTING, L. N.; POLTRONIERI, T. P.; SILVA, R. C.; GIOIELLI, L. A. Crystallization behavior of structured lipids by chemical interesterification of milk fat and sunflower oil. Food Science and Technology, v. 30, n. 1, p. 258-267, 2010. http://dx.doi.org/10.1590/S0101-20612010000100038.
RØNNE, T. H.; YANG, T.; MU, H.; JACOBSEN, C.; XU, X. Enzymatic interesterification of butterfat with rapeseed oil in a continuous packed bed reactor. Journal of Agricultural and Food Chemistry, v. 53, n. 14, p. 5617-5624, 2005. http://dx. doi. org/10.1021/jf050646g. PMid:15998124.

ROUSSEAU, D.; MARANGONI, A. G. The effects of interesterification on physical and sensory attributes of butterfat and butterfatcanola oil spreads. Food Research International, v. 31, n. 5, p. 381-388, 1998. http://dx.doi.org/10.1016/S0963-9969(98)00100-8.

SILVA, R. C.; COTTING, L. N.; POLTRONIERI, T. P.; BALCAO, V. M.; DE ALMEIDA, D. B.; GONCALVES, L. A. G.; GRIMALDI, R.; GIOIELLI, L. A. The effects of enzymatic interesterification on the physical-chemical properties of blends of lard and soybean oil. Lebensmittel-Wissenschaft + Technologie, v. 42, n. 7, p. 1275-1282, 2009. http://dx.doi.org/10.1016/j.Iwt.2009.02.015.

WANG, B.; XU, S.; SUN, D. Application of the electronic nose to the identification of different milk flavorings. Food Research International, v. 43, n. 1, p. 255-262, 2010. http://dx.doi. org/10.1016/j.foodres.2009.09.018.

WILSON, A. D.; BAIETTO, M. Applications and advances in electronic-nose technologies. Sensors, v. 9, n. 7, p. 5099-5148, 2009. http://dx.doi.org/10.3390/s90705099. PMid:22346690. 
Effect of the catalyst on the physical and aroma attributes of interesterified milk fat-vegetable oil blends

Rocha, M. R. et al.

\section{Supplementary Material}

Supplementary material accompanies this paper.

Olfactory profiles of the principal components before and after the chemical and enzymatic interesterification reactions of the binary blends (Figs. S1-S4).

This material is available as part of the online article from http://www.scielo.br/IDSCIELO 